\title{
Performance Evaluation to Develop an Engineering Scale Cathode Processor by Multiphase Numerical Analysis
}

\section{다상유동 전산모사를 통한 공학 규모의 cathode processor의 성능평가}

\author{
Bung Uk Yoo ${ }^{1}$, Sung Bin Park ${ }^{2}$, Sang Woon Kwon², Jeong Guck Kim², Han Soo Lee ${ }^{2}$, In Tae Kim², and Jong Hyeon Lee ${ }^{1 *}$ \\ ${ }^{1}$ Chungnam National University, 99 Daehak-ro, Yuseong-gu, Daejeon, Korea \\ ${ }^{2}$ Korea Atomic Energy Research Institute, 111 Daedeok-daero 989, Yuseong-gu, Daejeon, Korea \\ 유병욱 ${ }^{1}$, 박성빈 ${ }^{2}$, 권상운 ${ }^{2}$, 김정국 ${ }^{2}$, 이한수 ${ }^{2}$, 김인태 ${ }^{2}$, 이종현 ${ }^{*}$ \\ 1충남대학교, 대전광역시 유성구 대학로 99 \\ 2한국원자력연구원, 대전광역시 대덕대로 989번길 111
}

(Received December 27, 2013 / Revised March 12, 2014 / Approved March 19, 2014)

Molten salt electrorefining process achieves uranium deposits at cathode using an electrochemical processing of spent nuclear fuel. In order to recover pure uranium from cathode deposit containing about 30wt\% salt, the adhered salt should be removed by cathode process $(\mathrm{CP})$. The $\mathrm{CP}$ has been regarded as one of the bottle-neck of the pyroprocess as the large amount of uranium is treated in this step and the operation parameters are crucial to determine the final purity of the product. Currently, related research activities are mainly based on experiments consequently it is hard to observe processing variables such as temperature, pressure and salt gas behavior during the operation of the cathode process. Hence, in this study operation procedure of cathode process is numerically described by using appropriate mathematical model. The key parameters of this research are the amount of evaporation at the distillation part, diffusion coefficient of gas phase salt in cathode processor and phase change rate at condensation part. Each of these conditions were composed by Hertz-Langmuir equation, Chapman-Enskog theory, and interphase mass flow application in ANSYS-CFX. And physical properties of salt were taken from the data base in HSC Chemistry. In this study, calculation results on the salt gas behavior and optimal operating condition are discussed. The numerical analysis results could be used to closely understand the physical phenomenon during $\mathrm{CP}$ and for further scale up to commercial level.

Keywords: Cathode process, Ansys-CFX, Hertz-Langmuir eq., Pyroprocess, Numerical analysis

용융염 전해정련공정은 사용후핵연료로부터 전기화학적인 방법을 통해 음극에서 우라늄을 회수 하는 공정이다. 이 때 우라 늄은 약 30wt\%의 염을 포함하고 있어 순수한 우라늄을 얻기 위해서는 염을 제거하는 Cathode Process (CP)가 필수적이다. $\mathrm{CP}$ 는 대량의 우라늄을 처리해야 하므로 파이로공정의 난관중의 하나로 인식되고 있으며, 우라늄의 순도가 최종적으로 결정 되는 단계이므로 매우 중요한 공정이다. 현재, 이에 대한 연구는 주로 실험적 방법에 근거 하고 있어 염 제거 공정 중 온도, 압력, 염 가스의 거동을 관찰하기 어렵다. 따라서 본 연구에서는, 공정의 운전 조건에 대해 적합한 수학적 모델을 이용하여 전산모사 해석을 진행하였다. 본 연구는 증류부에서 염 가스의 증류 량, 확산계수에 의해 계산된 장치 내 염 가스의 이동 그 리고 응축부에서의 응결속도를 중점적으로 연구하였다. 장치내의 각각의 염 가스 거동을 정의하기 위해 Hertz-Langmuir 관 계식, Chapman-Enskog Theory, ANSYS-CFX의 상용 코드를 사용하였다. 그리고 HSC Chemistry에서 염의 물성 값을 이용 하여 모델을 구성하였다. 본 연구의 전산모사 해석을 통해 얻은 연구 결과를 이용하여 염 가스의 거동과 장치의 최적 운전 조건을 예측하였다. 따라서 본 해석 결과는 $\mathrm{CP}$ 의 물리적 현상을 깊게 이해하는데 쓰일 뿐 아니라, 공학규모의 $\mathrm{CP}$ 장치를 상 용규모로 확장하는데 이용 할 수 있다.

중심단어: 염증류, Ansys-CFX, Hertz-Langmuir 방정식, 파이로 공정, 전산모사 
Bung Uk Yoo et al. : Performance Evaluation to Develop an Engineering Scale Cathode Processor by Multiphase Numerical analysis

\author{
*Corresponding Author. \\ Jong Hyeon Lee, Chungnam National University, E-mail: jonglee@cnu.ac.kr, Tel: +82-42-821-6596
}

\section{1.서 론}

사용후핵연료를 재활용 하는 기술에는 크게 습식공정 (aqueous process)와 건식공정(nonaqueous process)이 있 다. 현재는 습식공정이 상용화 되어있으며, 공정 중 잔류 우 라늄이나 초우라늄 원소등으로 구성된 폐기물들이 다량 발 생한다[1]. 반면에 파이로 공정(Pyroprocess)은 폐기물 발생 량을 줄이며 사용후핵연료의 위험 요소를 제거하는 대안으 로 주목 받고 있다. 또한 파이로 공정를 통해 생산한 금속 핵 연료는 방사능 위험도와 부피가 크게 감소 할 뿐 아니라, 4 세대 원자로인 SFR(Sodium Fast Reactor)에서 이용 가능하 다. 미국 Argonne National Labotory(ANL)에서는 금속핵연 료를 사용하는 Experimental Breeder Reactor II (EBR-II) 원자로의 사용후핵연료를 처리하는 공정으로 파이로 공정을 제안하여 이에 대한 기술 개발이 진행되었다[2]. 한국원자력 연구원에서도 PWR(Pressurized Water Reactor)에서 발생한 산화물 형태의 사용후핵연료를 재활용할 수 있는 방안으로 파이로 공정을 채택하여 상용화를 목표로 연구를 진행하고 있다. 한국원자력연구원(KAERI)에서 수행하고 있는 파이로 공정은 PWR에서 나오는 사용후핵연료를 피복관에서 제거 하는 Head-end 공정과 산화물 형태의 사용후핵연료를 금속 형태로 환원시키는 전해 환원공정, 우라늄만을 회수하는 전 해 정련공정, 전해 정련공정 후 잔류 우라늄과 TRU 원소 등 을 함께 회수하는 전해 제련공정, 공정 중 사용하는 용융염 을 처리하는 염 폐기물 공정으로 이루어져 있다[3,4]. 특히, 전해 정련공정은 사용후핵연료로부터 금속형태의 우라늄을 전기화학적인 방법을 통해 회수하는 공정으로 수지상의 전 착물 내에 $30 \mathrm{wt} \%$ 이상의 염을 포함하고 있어, 차후 SFR의 연 료로 사용되거나 장기 보관을 위해 반드시 제거되어야 한다.

염 증류 공정인 cathode process $(\mathrm{CP})$ 의 국제적 연구를 보면, 미국 경우 INL에서 EBR-II 사용후핵연료를 처리하기 위해 구축한 Fuel Conditioning Facility(FCF) hot cell에 유 도로가 장착된 $\mathrm{CP}$ 장치를 설치하여 공학규모의 실험을 진행 하였다. 공정에 사용된 물질은 음극에서 회수한 우라늄, 염 그리고 잔류 카드늄이 함유되어 있다. 염의 경우 공정 조성 의 $\mathrm{LiCl}-\mathrm{KCl}$ 염이며, 온도조건과 압력조건을 변화하였다. [56]. 일본의 염 증류 공정에 관한 연구로는 Central Research Institute of Electric Power Industy(CRIEPI)에서 주도적으
로 수행하고 있었으나 Japan Atomic Energy Agency(JAEA) 와의 공동연구를 통해 염 증류 장치에 관한 연구를 진행하고 있다. 최근의 연구에서는 Liquid Cadmium Cathode에서 회 수한 전착물을 이용하여 연구를 진행하였다. 조성으로는 잔 류 카드늄과 우라늄 그리고 플루토늄이 함유되어 있으며 공 정 온도는 $800^{\circ} \mathrm{C}$ 이며 $10 \mathrm{~g}$ 규모의 작은 장치로 연구를 진행 하였다[7]. 최근 KAERI에서는 염 증류 효율을 증대시키기 위 한 연구로, 도가니의 재질 및 형태, 연속식 염 증류 방식 등 을 연구하고 있다.

효율성을 높이기 이해 가장 중요한 고려사항은 염의 증 류량 증대, 염 가스의 이동 경로 최소와 효율적인 응축 공정 설계이다. 하지만 운전 조건이 고온이기 때문에 내부를 관 찰하기 어렵고 기액제어 공정이기 때문에 공정변수를 최적 화 할 수 있는 전산모사 과정이 선행되어야 한다. 따라서 본 연구에서는 실험실 규모의 $\mathrm{CP}$ 장치의 2 가지 모델을 구축하 고, 각 모델 별 염 가스의 이동 흐름과 온도 분포를 예측하 여 적합한 모델을 선정하는 것을 목적으로 한다. 각 모델에 서 염 가스의 증류, 이동, 응축은 각각 Hertz-Langmuir 식, Chapman-Enskog 이론이 적용된 Fick의 법칙, 압력분포와 온도분포에 따라 이뤄지며 $\mathrm{Ar}$ 가스와 염 가스의 유동 해석을 동시에 진행하는 다상유동해석을 기반으로 하여 수행하였다 [8]. 연구에 적용된 증류계수 등 일부 변수는 실험 값[9]을 기 반으로 전산모사하였다.

\section{2. 이론적 배경 및 실험 방법}

\section{1 증류 속도}

본 연구는 염 가스와 아르곤 가스등의 다상유동 해석이 포함된 도메인 내의 열 분포와 염 가스의 증류, 이동, 응축의 전산모사를 중점으로 수행하였다. 도가니 내에 염의 증류량 을 결정하기 위해 사용된 이론인 Hertz-Langmuir 식은 기체 운동론에 기반한 방정식으로, 진공 조건에서 식 (1)과 같이 기술 할 수 있다[10].

$$
J_{\mathrm{HL}}=\frac{\alpha \mathrm{P}}{\sqrt{2 \pi \mathrm{MRT}}}
$$


$\mathrm{J}_{\mathrm{HL}}$ 은 증류 속도이며 $\alpha$ 는 Hertz-Langmuir 계수이다. P, $\mathrm{M}, \mathrm{R}, \mathrm{T}$ 는 각각 증발 원소의 증기압, 몰 질량과 이상기체 상 수, 장치의 운전 온도를 나타낸다. 본 전산모사 연구에서는 압력조건이 purge gas가 없는 조건에서 0.5 torr이며 $\alpha$ 값을 0.049 로 정의하였다. 이 값은 일반적으로 $\alpha$ 값이 0.1 이상인 점에 비해 다소 작은 값인데, 이는 기존 실험 결과[9]와 조건 을 기반으로 도출된 값이며, $\mathrm{CP}$ 공정에서 $\alpha$ 값이 이론 값 대 비 6-8\%를 가진다는 연구 결과와[11] Purge gas가 있는 경우 $\alpha$ 값이 5.8×. $8^{-5}$ 까지 하다는 연구결과를[12,13] 통해 물리적으 로 타당한 값으로 여겨 본 해석에 사용하였다. 결과적으로 염의 증류량은 Hertz-Langmuir 식을 기반으로 한 온도에 따 른 염의 증기압과 공정 압력 조건에 따라 결정된다. 증류 모 델에 따라 염의 이동은 농도 분포와 온도 압력 조건에 따라 속도가 달라지며 이때 염 가스의 확산 지배방정식은 Fick의 법칙을 따른다. Fick의 확산 방정식은 식 (2)로 표현 할 수 있 다[14].

$$
\frac{\partial \mathrm{C}}{\partial \mathrm{t}}=\nabla \cdot\left(\rho \mathrm{D}_{\mathrm{AB}} \nabla \phi\right)+\mathrm{S}_{\phi}
$$

$\rho$ 는 혼합물의 단위 부피당 질량인 밀도를 나타내며, $\phi$ 는 단위 질량당 보존되는 양 ( C / $\rho$ )을 의미한다. $S_{\phi}$ 는 단위 부피당 관계되는 입력 값인 소스항으로서 전산해석에 있어 추가적 계산이 필요할 때 입력되는 값이다(없는 경우 0). 여 기서 $\mathrm{D}_{\mathrm{AB}}$ 는 확산 계수 값으로 기체 운동론에 기반하여 계산

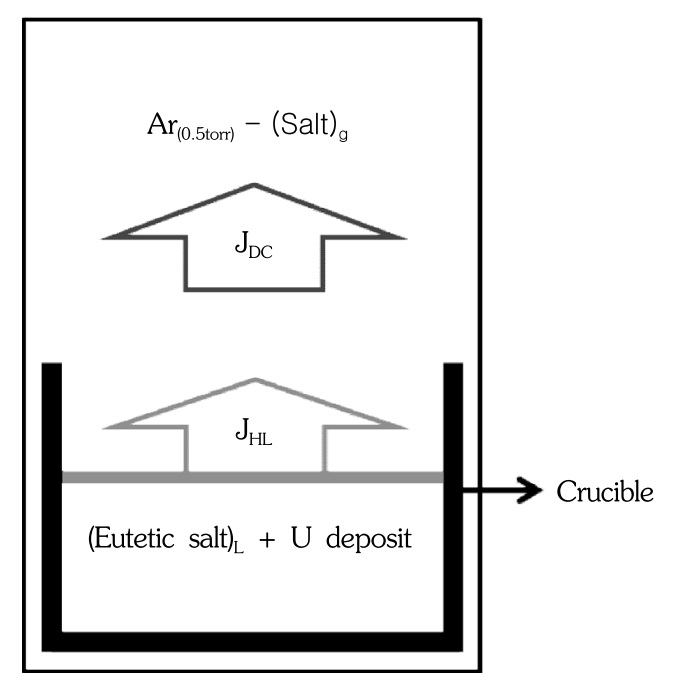

Fig. 1. Schematic Behavior of salt in the cathode processor.
된다. 이 값은 식 (3)에 표현 하였다[15].

$$
\mathrm{D}_{\mathrm{AB}}=\frac{1.86 \times 10^{-3} \mathrm{~T}^{3 / 2}}{\mathrm{p} \sigma_{\mathrm{AB}}^{2} \Omega_{\mathrm{D}_{\mathrm{AB}}}} \sqrt{\frac{1}{\mathrm{M}_{\mathrm{A}}}+\frac{1}{\mathrm{M}_{\mathrm{B}}}}
$$

$\mathrm{D}_{\mathrm{AB}}$ 는 확산 계수로 증류된 염 가스의 이동에 큰 영향 을 미치는 인자이다. T, p, $\sigma_{\mathrm{AB}}, \Omega_{\mathrm{D}_{\mathrm{AB}}}$ 는 각각 운동 온도와 압력, Lennard-Jones 변수와 충돌 함수를 의미한다. 위 식은 실제 상황과 비교 했을 때 $80 \%$ 의 정확성을 가지며, HertzLangmuir 식과 연계하여 염 가스의 증류 이동 모델을 구성 한다. 그 구성도는 Fig. 1에 표현하였다. 증류된 염가스의 양 은 Hertz-Langmuir 식으로 계산과 Fick의 법칙에 의해 $\mathrm{Ar}$ 기 체 안으로 확산된다. 염의 이동을 결정하는 $\mathrm{J}_{\mathrm{DC}}$ 는 확산계수 $\mathrm{D}_{\mathrm{AB}}$ 를 가지며 운전 온도, 압력 등에 의존한다.

\section{2 응축모델}

염의 응축 모델은 응축부 한정 염 가스 응축 모델(M-1), 염의 증기압에 따른 응축 모델(M-2)이 있다. 응축부 한정 염 가스 제거 모델의 경우 일정 온도를 가지는 지역에서 염 응축 이 일어나 염 가스가 응축되는 것이고, 증기압에 따른 응축 모델은 장치 내 온도에 따라 정해진 염의 증기압 증감이 적용 되어 염 가스가 응축되는 모델이다. M-1 모델은 장치 하단인 응축부 외벽의 염 가스의 농도를 0 으로 고정하여 염 가스를 응축시키는 방법이다. M-2 모델은 염 증기압을 이용하여 장 치 전체에서 염 가스를 응축시키는 방법으로 염의 증기압은 $\mathrm{LiCl}$ 의 염 증기압을 이용하였다. 이는 $\mathrm{NaCl}-\mathrm{KCl}$ 혼합 염과 $\mathrm{KCl}$ 개별 염에 대한 증기압 차이가 약 $25 \mathrm{~Pa}$ 이며, 증류 속도 차이는 $0.2 \mathrm{~g} / \mathrm{cm}^{2} \mathrm{~h}$ 로서 다소 차이는 나지만, 본 연구는 장치 형상에 대한 상대 성능비교에 중점을 두어 이러한 $\mathrm{LiCl}-\mathrm{KCl}$ 공융염과 $\mathrm{LiCl}$ 염의 거동 차이는 크게 문제가 되지 않을 것으 로 판단되어 $\mathrm{LiCl}$ 염으로 가정하였다. 또한 $\mathrm{KCl}$ 염의 녹는점 은 $770^{\circ} \mathrm{C}, \mathrm{KCl}-\mathrm{NaCl}$ 혼합 염의 녹는점은 $506^{\circ} \mathrm{C}$ 로 $260^{\circ} \mathrm{C}$ 이상 차이가 나지만, G. Bourgès 등의 연구 결과에 따르면, $\mathrm{KCl}$ 단일 염과 $\mathrm{KCl}-\mathrm{NaCl}$ 혼합 염의 증류 속도 차이는 각각 $3.6 \mathrm{~g} /$ $\mathrm{cm}^{2} / \mathrm{h}$ 과 $3.8 \mathrm{~g} / \mathrm{cm}^{2} / \mathrm{h}$ 로 단일염이 $0.2 \mathrm{~g} / \mathrm{cm}^{2} / \mathrm{h}$ 작아, 그 차이 가 $10 \%$ 미만이다[11]. 이는 $\mathrm{LiCl}-\mathrm{KCl}$ 염과도 동일한 현상이 일어날 것으로 판단 되며 $\mathrm{LiCl}-\mathrm{KCl}$ 공융염의 증류와 $\mathrm{LiCl}$ 단일 염의 거동이 유사 할 것이라는 근거가 된다. 하지만 궁극적으 로 모델을 완성 하기 위해서는 파이로공정에 사용되는 $\mathrm{LiCl}-$ $\mathrm{KCl}$ 공융염과 본 연구에서 사용한 $\mathrm{LiCl}$ 염의 녹는점이 다르 
Bung Uk Yoo et al. : Performance Evaluation to Develop an Engineering Scale Cathode Processor by Multiphase Numerical analysis

기 때문에 증류 거동 뿐 만 아니라 응축 거동이 달라지게 되 어, 공융염을 이용한 추가적인 연구를 진행 할 예정이다. 따 라서 응축 모델은 $\mathrm{LiCl}$ 염 가스의 응축 영역이 장치 하단으로 제한되는 방법과 장치 전체에서 일어나는 방법으로 구분하 여 모델을 구성하였다. 하단부 외벽의 염 가스의 농도는 M-1 모델의 경우, '0'이며 M-2 모델의 경우 거의 '0’에 가깝다. M-2 모델에서 사용한 $\mathrm{LiCl}$ 염의 증기압은 다음과 같다[16].

$$
\mathrm{P}_{\text {salt }}=10^{(12.08-10760 / \mathrm{T})}
$$

식 (4)은 Atonine 방정식을 간소화 한 August 방정식에서 증기압에 따라 정리해 놓은 것이다. 여기서 계산된 증기압은 M-1, M-2 모델에서 사용된 Hertz-Langmuir 방정식에서 증류 량을 결정하는데 적용 될 뿐 아니라, M-2 모델에서 $\mathrm{CP}$ 장치 내에서 온도에 따라 변하는 값을 이용하여 응축모델에 적용 하였다. 계산된 증기압은 $\mathrm{CP}$ 장치 내 염을 온도에 비례하여 감소시키는데 이용하였다. 자료의 신뢰성 검증을 위하여 HSC Chemistry를 이용하여 계산된 $\mathrm{LiCl}$ 의 증기압과 비교하 였으며, 증기압계산은 식 (5)에 의해 수행되었으며, Reaction Equations module을 사용하였다.

$$
\mathrm{LiCl}=\mathrm{LiCl}(\mathrm{g}), \quad \mathrm{K}=\frac{\mathrm{p}_{\mathrm{LiCl}}}{\mathrm{a}_{\mathrm{LiCl}}}=\mathrm{p}_{\mathrm{LiCl}}
$$

여기서 $\mathrm{K}$ 는 평형상수, $\mathrm{PLiCl}$ 및 $\mathrm{aLiCl}$ 은 각각 $\mathrm{LiCl}$ 의 증기 압 및 활동도이다. 식 (4)와 식 (5)를 통해 계산된 증기압 비 교 값을 Fig. 2에 도시 하였다. 각기 증기압 값은 운전 온도 구간인 400-1200 K에서 유사한 값을 나타내며, 이를 통해 식

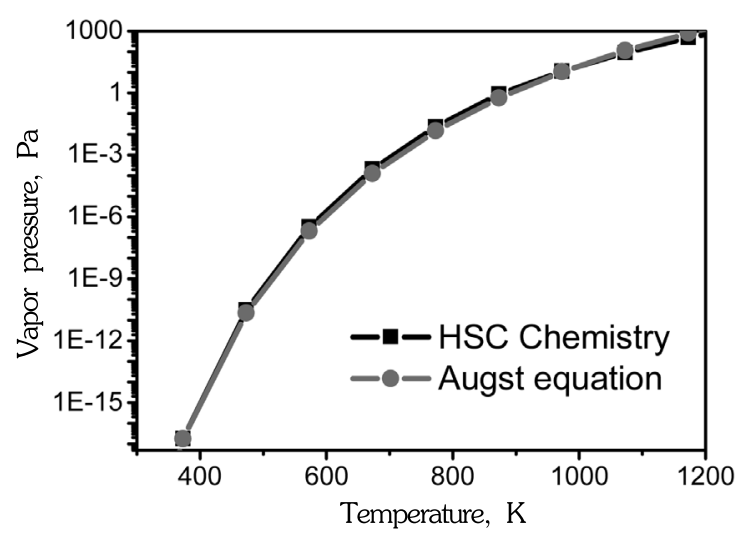

Fig. 2. Comparing vapor pressure of HSC Chemistry and August equation.
(4)의 신뢰성에 문제가 없다는 것을 검증하였다.

이렇게 계산된 기화 및 응축된 염의 양은 식 (6)에 의해 누적함수로 나타낼 수 있으며, 이를 통하여 시스템 내에 잔류 하는 총 염의 양을 계산하여 염 증류 공정의 종료 시점을 비 교 평가하는데 사용하였다.

$$
\mathrm{W}_{\text {con }}=\sum \text { Condensed amount of Salt gas }
$$

\section{$2.3 \mathrm{CP}$ 내 열전달}

$\mathrm{CP}$ 장치에서의 열전달은 공정이 진공에서 이루어지므로 대류 열 전달 이외에 복사열전달에 의한 기여가 크다. 따라 서 Discrete Transfer 복사열전달 모델을 적용하여 $\mathrm{CP}$ 장치 내의 온도분포를 계산하였다. 복사 열전달 모델은 식 (7)와 같다[14].

$I_{v}(r, s)=I_{v o} \exp \left(-\left(K_{a v}+K_{s v}\right) s\right)+I_{b v}\left(1-\exp \left(-K_{a} s\right)\right)+K_{s v} \bar{I}_{v}$

식 (7)에서 $\mathrm{I}_{\mathrm{vo}}, \mathrm{I}_{\mathrm{v}}, \mathrm{I}_{\mathrm{bv}}$ 는 각각 경계면을 떠난 복사강도, 평 균 복사강도, 위치와 방향에 따른 흑체복사강도를 의미한다. $\mathrm{K}_{\mathrm{a}}$ 와 $\mathrm{K}_{\mathrm{s}}$ 는 각각 흡수계수와 산란계수이며, $\mathrm{K}_{\mathrm{av}}$ 와 $\mathrm{K}_{\mathrm{sv}}$ 는 각각 스펙트럼의 흡수계수와 산란계수로 각각 $1 \mathrm{~m}^{-1}, 0 \mathrm{~m}^{-1}$ 값을 사용하였다. $r$ 과 $s$ 는 각각 위치와 방향 벡터를 의미한다. 식 (7)는 평균 복사강도를 적분하여 열 유속을 계산하여 열 전달 식에 추가하게 된다. 한편 열전달 계산에 필요한 경계조건은 $\mathrm{CP}$ 장치 내 각각 일정한 온도로 유지되는 5 구간으로, Table 1 에 도시하였다. 이 값은 높이에 따라 온도구배를 계단함수 를 이용하여 입력하였으며, Fig. 3에 도식적으로 나타내었다.

\section{4 실험방법}

본 연구 실험 조건에 기반이 되는 실제 실험 조건과 결 과는 Table 2에 정리하여 나타내었다. 공정 온도는 증류부 $900^{\circ} \mathrm{C}$ 이며 응축부는 상온이다. 압력은 초기 $\mathrm{Ar}$ 으로 500 torr 까지 진공을 가한 후 온도를 $900^{\circ} \mathrm{C}$ 까지 상승시킨 후 0.5 torr 진공 상태로 하여 조업을 시작한다. 장치의 상부는 직경 40 $\mathrm{cm}$ 하부 직경 $30 \mathrm{~cm}$ 높이 $121 \mathrm{~cm}$ 이다. 염이 담겨 있는 도 가니의 크기는 직경 $20 \mathrm{~cm}$, 높이 $30 \mathrm{~cm}$ 이다. 여기서 실험은 수지상의 우라늄이 포함되지 않은 순수 염의 증류 공정이다. 조업 결과 염의 증류 속도는 $10 \mathrm{~g} / \mathrm{cm}^{2} \mathrm{~h}$ 이며, 이를 통해 계 
산된 증류 계수 $(\alpha)$ 는 0.049 이다. 이 실험 조건과 결과를 바 탕으로 전산모사 모델의 초기조건 경계조건을 구성하였다.

실험실 규모의 $\mathrm{CP}$ 장치 전산모사를 위해 응축 방법에 따 라 2 가지 모델을 제시하였다. 응축부 한정 염 가스 응축 모 델(M-1), 염의 증기압에 따른 응축 모델(M-2)로 각각 같은 구 조인자 조건과 메시 조건을 가진다. 모델 별 경계조건과 초 기조건은 Table 1에 표현하였다. 이 값은 참고문헌 [9]의 실 험 조건과 유사한 값으로 실제 실험에서 공정이 시작되는 압 력인 0.5 torr에서부터 계산이 시작된다. 공학 규모의 $\mathrm{CP}$ 장 치의 전산모사를 위해 $\mathrm{CP}$ 장치의 구조와 메시 형상을 Fig. 4

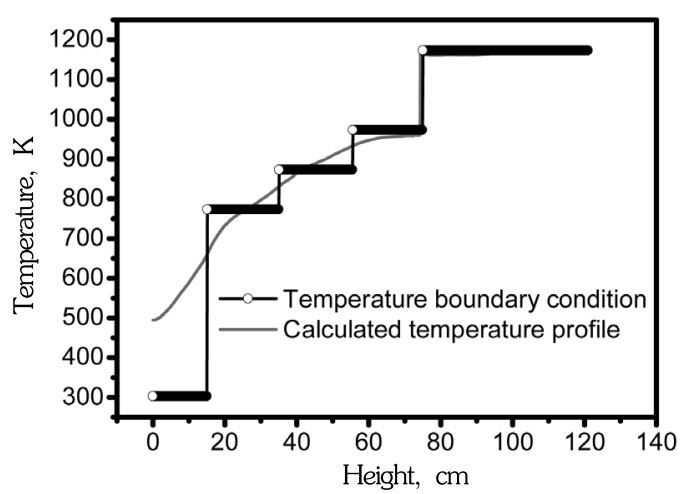

Fig. 3. Temperature distribution according to height of Cathode Processort.

Table 1. Boundary and Initial condition

\begin{tabular}{|c|c|c|}
\hline & M-1 & M-2 \\
\hline Temperature & $\begin{array}{c}\text { If }\left(\mathrm{y}^{*} 1\left[\mathrm{~T}^{\wedge}-1\right]<0.75 \text {,step }\left(\mathrm{y} * 1\left[\mathrm{~m}^{\wedge}-1\right]-0.15\right) * 773\right. \\
{[\mathrm{K}]+\text { step }\left(\mathrm{y} * 1\left[\mathrm{~m}^{\wedge}-1\right]-0.35\right) * 100[\mathrm{~K}]+\text { step }\left(\mathrm{y} * 1\left[\mathrm{~m}^{\wedge}-\right.\right.} \\
1]-0.55) * 100[\mathrm{~K}], 1173[\mathrm{~K}]) \\
\text { Shown in Fig. } 3\end{array}$ & $\begin{array}{c}\text { If }\left(\mathrm{y}^{*} 1\left[\mathrm{~T}^{\wedge}-1\right]<0.75, \text { step }\left(\mathrm{y} * 1\left[\mathrm{~m}^{\wedge}-1\right]-0.15\right) * 773\right. \\
{[\mathrm{K}]+\operatorname{step}\left(\mathrm{y} * 1\left[\mathrm{~m}^{\wedge}-1\right]-0.35\right) * 100[\mathrm{~K}]+\operatorname{step}\left(\mathrm{y} * 1\left[\mathrm{~m}^{\wedge}-\right.\right.} \\
1]-0.55) * 100[\mathrm{~K}], 1173[\mathrm{~K}]) \\
\text { Shown in Fig. } 3\end{array}$ \\
\hline Initial Pressure & 0.5 torr & 0.5 torr \\
\hline Molar mass of Salt & $42.394 \mathrm{~g} / \mathrm{mol}$ & $42.394 \mathrm{~g} / \mathrm{mol}$ \\
\hline Amount of initial Salt & $70 \mathrm{~g}$ & $70 \mathrm{~g}$ \\
\hline Evaporation rate & $10 \mathrm{~g} / \mathrm{cm}^{2} \mathrm{~h}$ & $10 \mathrm{~g} / \mathrm{cm}^{2} \mathrm{~h}$ \\
\hline Time Condition & $0 \sim 100,0.1$ & $0 \sim 100,0.1$ \\
\hline Model & Limited condensation region model & Considered vapor pressure model \\
\hline
\end{tabular}

Table 2. Experimental conditions and results

\begin{tabular}{|c|c|c|}
\hline \multirow{9}{*}{ Conditions } & Operation temperature & $1173 \mathrm{~K}$ \\
\hline & Operation pressure & 0.5 torr \\
\hline & Salt & $\mathrm{LiCl}+\mathrm{KCl}$ eutectic \\
\hline & Upper part diameter of cathode processor & $40 \mathrm{~cm}$ \\
\hline & Bottom part diameter of cathode processor & $30 \mathrm{~cm}$ \\
\hline & Diameter of crucible & $20 \mathrm{~cm}$ \\
\hline & Diameter of thermal radiation shield & $38 \mathrm{~cm}$ \\
\hline & Height of cathode processor & $121 \mathrm{~cm}$ \\
\hline & Height of crucible & $30 \mathrm{~cm}$ \\
\hline \multirow{2}{*}{ Results } & Evaporation rate & $10 \mathrm{~g} / \mathrm{cm}^{2} \mathrm{~h}$ \\
\hline & Evaporation coefficient & 0.049 \\
\hline
\end{tabular}




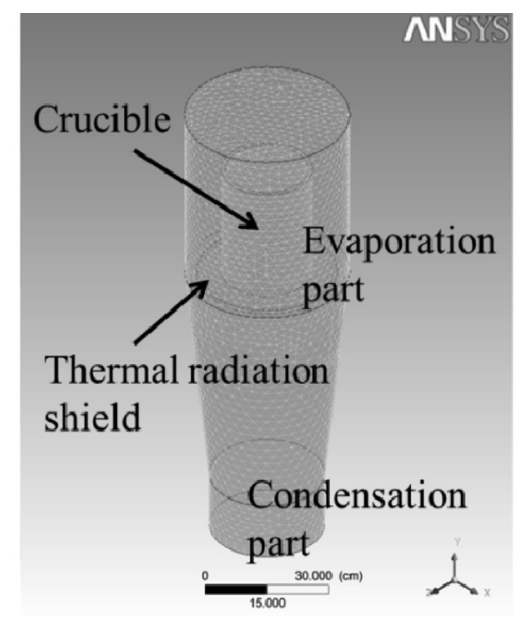

Fig. 4. Geometry factor of 3D cathode process.

와 같이 설계하였다. 총 메시 개수는 130,594 개 이며 증류 부와 응축부에 더 조밀한 구조를 가지는 메시로 설계하였다. 장치의 크기는 높이 $121 \mathrm{~cm}$, 증류부 직경 $40 \mathrm{~cm}$, 응축부 직 경 $28 \mathrm{~cm}$, 방열판의 넓이는 $34 \mathrm{~cm}$ 이다. 내부 도가니의 경우 직경 $20 \mathrm{~cm}$, 높이 $30 \mathrm{~cm}$ 로 이루어져 있다. 초기 압력조건은 0.5 torr이고 이후 압력은 모델에 따라 상변이가 진행 되는 곳 마다 다르게 계산된다. 장치 내 온도는 증류와 응축이 유도 되도록 설계된 실제 공정에서 사용되는 온도구배 조건을 적 용하여 계산을 진행 하였으며 Fig. 3에 나타내었다. 염 가스 의 증류는 Fig. 4 의 증류부에 위치한 도가니 바닥에서 시작 되며, 그 값은 Hertz-Languir 식을 통하여 $0.87222 \mathrm{~g} / \mathrm{s}$ 로 계 산하고, 초기 염의 장입량은 계산 시간을 고려하여 $70 \mathrm{~g}$ 으로 하였다. 실제로 $\mathrm{CP}$ 중의 염 증류 및 응축은 초기 개시지점 및 종료지점을 제외하고는 정상상태로 유지되므로 형상에 따른 증류효율 평가를 위한 본 연구에서는 큰 의미가 없어 실제 장 입량 보다 작은 $70 \mathrm{~g}$ 의 염 양은 충분하다고 판단하였다. 계산 시간은 0.1 초 간격으로, 총 100 초간 증류된 염 가스의 이동 과 응축을 전산모사 하였다. 계산 시간은 염 증류를 시작하 여, 장치 내 염 가스 양의 20초에서 평형 상태로 존재하게 되 고, 증류 완료 후 30초 이내로 잔여 염 가스가 “0”으로 수렴해 가는 것을 기반으로 지정 하였다.

$\mathrm{CP}$ 장치의 형상에 따른 증류 거동을 관찰 하기 위해 방 열판의 형상을 변화 시켰다. 첫째로 방열판의 직경변화와 두 께변화를 주어 각각의 변수에 따른 온도 변화와 증류 거동을 관찰하였다. 방열판의 직경변화는 $26 \mathrm{~cm}$ 부터 $4 \mathrm{~cm}$ 간격으
로 $38 \mathrm{~cm}$ 까지 변화 시켰고, 두께변화는 $10 \mathrm{~mm}, 20 \mathrm{~mm}, 30$ $\mathrm{mm}$ 로 변화시켜 전산모사를 진행하였다.

본 전산모사 연구의 목적은 실제 실험에 적합한 증류모 델을 제시하고, 각 모델별 방열판 직경과 두께에 따른 증류된 염 가스의 거동을 예측하여 가장 최적의 방열판 크기 조건을 제시하는 것이다. 따라서 참고문헌 [9]에서 사용된 조건으로 구조인자와 경계조건을 설정하여 전산 모사를 진행하였다.

\section{3. 결과 및 고찰}

기존 전해정련공정 후 우라늄 전착물에 대한 실험실 규 모의 $\mathrm{CP}$ 에 대한 연구로서 Hertz-Langmuir 관계식을 이용하 여 실험적인 고찰을 수행한 결과 온도 및 내부 압력에 따른 증류계수를 도출한 바 있으며 [8], 수지상의 우라늄 금속으로 부터 염 증류공정에 대한 기초적 현상을 파악한 바 있다. 또 한 참고문헌 [11]의 Gilles Bourgès 등의 연구와 비교하여 보 면, 본 연구에서 적용된 $\alpha$ 을 사용하고 참고문헌의 온도, 압력 조건과 $\mathrm{KCl}$ 염의 물성을 사용하여 Hertz-Langmuir 관계식 에 적용하면 1.51-4.02 g/ $\mathrm{cm}^{2} \mathrm{~h}$ 의 증류 속도 값을 얻을 수 있 다. 이 값은 참고문헌에서 명시한 3.6의 값과 큰 차이가 없 다. 또한 참고문헌의 $\mathrm{KCl}$ 증류 실험 결과를 기반으로 하여 도 출한 $\alpha$ 값은 0.094-0.037로 본 연구에서 사용한 $\alpha$ 값과 유사 하여, 전산 모사에 사용된 $\alpha$ 값은 큰 오류가 없는 것으로 판 단할 수 있다. 또한 Table 2 증류속도와 참고문헌 [11]의 증 류속도를 비교하여 볼 때, 염의 종류와 증류 온도 조건이 달 라 차이가 나는 것으로 판단된다. 따라서 본 해석에는 실험 적으로 도출된 증류계수와 Hertz-Langmuir 관계식을 이용하 고 Chapman-Enskog 이론을 확산 계수 도출에 적용하여 CP 장치에 관한 염증류 거동을 예측하고 더 진보된 모델을 제시 할 수 있는 도구를 개발하고자 열 유체 해석에 기반한 확산 및 응축모델을 연계하여 전산해석을 수행하였다.

$\mathrm{CP}$ 장치 내부 온도는 Fig. 3 과 같이 계산된다. 입력 값을 총 4단 가열 부를 두어 장치 내 온도를 실제 실험 값과 유사 하게 적용시켰다. 증류부에서는 일정한 온도를 유지하고 아 래로 내려갈수록 온도가 떨어지다가 응축부에서 최저 온도 를 나타낸다. 응축부의 경우 입력 값 보다 더 큰 온도를 나타 내는 이유는 가열부의 열을 충분히 식힐 수 있는 냉각이 수행 되지 않기 때문이다. 하지만 충분히 염이 응축 될 수 있는 온 도이기 때문에, $\mathrm{CP}$ 장치의 열 분포 전산모사 해석은 성공적 으로 수행 되었다. $\mathrm{Ar}$ 의 거동을 Fig. 5 에 도시 하였다. $\mathrm{Ar}$ 은 
대류에 의해 상승과 하강이 이뤄지며 그 평균 속도가 $1 \mathrm{~cm} / \mathrm{s}$ 이하로 매우 작다. Ar가스는 증류장치의 원주방향으로 회전 운동을 하며, Fig. 5(a), 최대 대류속도는 Fig. 5(b)와 같이 도 가니 내에서 관찰되었으며, 증류장치의 상하부 온도차이에 의해 형성된 대류가 효과적으로 일어남을 알 수 있다. 하단 부의 경우는 방열판 하부에서 가장 빠른 대류 속도를 나타 내며, 전반적으로 상승기류를 형성하고 있는데, 이는 응축부 의 온도가 상온으로 유지됨으로서 상대적으로 높은 온도의 가스가 상부로 이동함으로서 일어나는 현상으로 판단된다.

M-1, M-2 모델을 비교하기 위해, 모델 별 $\mathrm{CP}$ 장치내의 시간에 따른 염 가스의 거동을 Fig. 6에 나타내었다. 두 모델 모두 염 증류가 시작된 이후 20 초까지 장치 내 염 가스의 농 도가 높아지고, 그 이후 일정한 평형 상태를 유지 하다 증류 가 완료되는 78초 이후 감소하는 경향을 보인다. 하지만 응 축의 경우, M-1 모델은 염 가스의 농도 감소가 응축부 즉 장 치 하단에서만 일어나는 반면, M-2 모델은 장치 내 전체에서 온도에 따라 염 가스의 농도가 감소한다. 염 가스의 농도가 감소하는 것은 염 가스의 응축이 이뤄지는 것으로, 전체 구 간에서 온도에 따라 염 가스의 응축이 진행되는 M-2 모델이 M-1 모델 보다 물리적으로 타당하여 염 가스 전산모사에 더 적합하다고 판단된다. 한편 염 가스는 거동은 증류부에서 응 축부로 이동하는 것을 알 수 있다. 이는 $\mathrm{Ar}$ 가스와 함께 대류 가 일어지만 그 영향보다 염 가스의 확산에 의한 이동이 지배 적이기 때문에 일어나는 현상이라 판단된다. 계산된 조건의 고온, 진공 상태에서는 염 가스의 확산 계수 값이 0.317026 $\mathrm{m}^{2} / \mathrm{s}$ 으로 상온, 상압의 확산계수 값인 $0.0178085 \mathrm{~m}^{2} / \mathrm{s}$ 에 비 해 17 배 이상 높다. 반면에 $\mathrm{Ar}$ 의 이동속도는 평균 $1 \mathrm{~cm} / \mathrm{s}$ 로, 위 확산 계수 값에 비해 매우 작은 것을 알 수 있다. 이를 상 대비교 하기 위해 Fig. 6을 살펴 보면, 염가스가 이동하여 평 형 조건이 되는데 20초 이하가 필요하다. 따라서 증류부에서 응축부까지 염가스가 이동하는데 20초 이내가 소요되는 반 면, 높이 $121 \mathrm{~cm}$ 의 장치에서 $\mathrm{Ar}$ 이 증류부에서 응축부까지 이 동하는데 걸리는 시간은 평균 120 초이다. 이는 진공 조건이 기 때문에 $\mathrm{Ar}$ 농도가 희박하여 온도구배에 의한 대류 효과가 작아 이와 같은 현상이 일어나는 것으로 판단된다. 또한 Fig. 6의 시간에 따른 염 가스의 농도 분포를 통해 가시적으로 CP 장치 내 염 가스의 거동을 확인 할 수 있다. 이 때의 $\mathrm{CP}$ 장치 의 상부, 중부, 하부의 농도를 정량적으로 비교평가하기 위 하여 Fig. 7과같이 각 부위에서의 시간에 따른 농도변화를 도 시하였다. M-1, M-2 모델 모두 도가니에서의 염의 증류에 의 하여 상부에서 가장 높은 농도를 나타내며, 하부로 내려오면

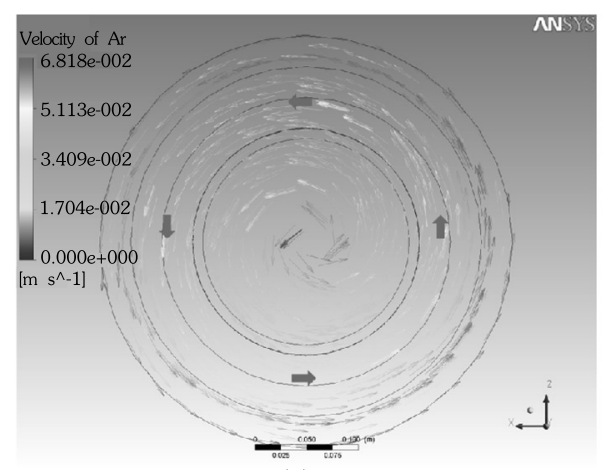

(a)

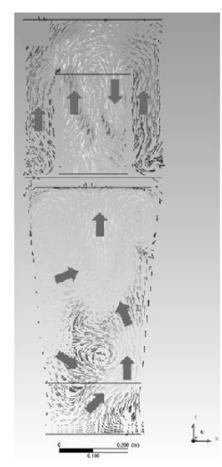

(b)
Fig. 5. Velocity of Ar distribution; (a)cross section (b) longitudinal section.
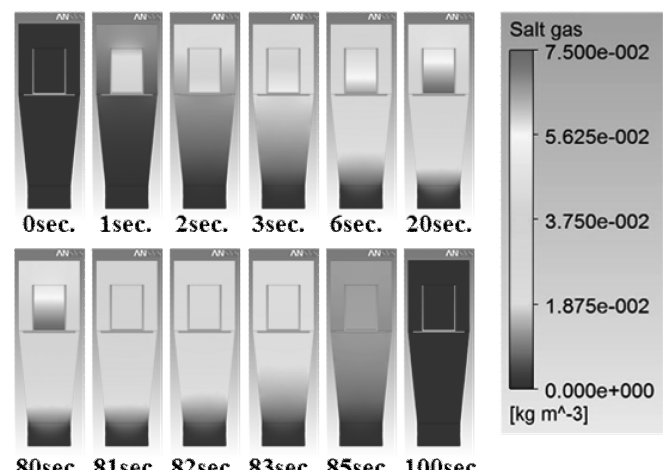

(a)
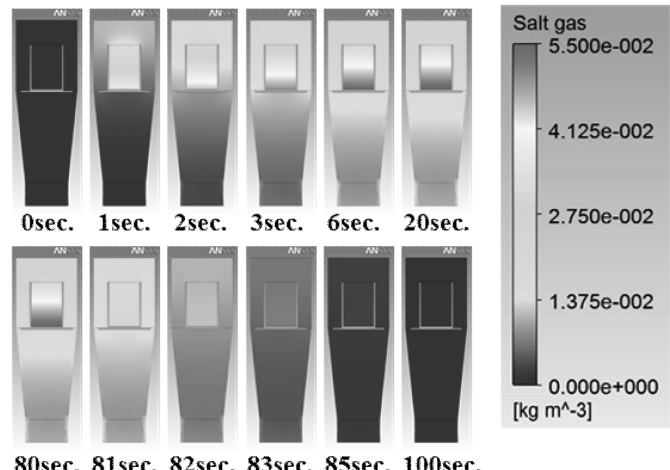

(b)

Fig. 6. Change of salt gas concentration over time in whole domain. (a) M-1 (b) M-2

서 농도가 낮아짐을 알 수 있다. 하지만 M-1 모델의 경우 응 축부인 하부에서만 염 가스의 응축이 일어나기 때문에 상대 적으로 다른 곳 보다 낮은 염 농도 값을 가지며, 중심부가 염 
Bung Uk Yoo et al. : Performance Evaluation to Develop an Engineering Scale Cathode Processor by Multiphase Numerical analysis

이 응축 가능한 온도임에도 불구하고 하부인 응축부와 상대 적으로 많은 차이를 보인다. 이는 염 가스의 응축이 진행되 지 않고 이동이 확산에 지배적으로 일어나기 때문에 일어나 는 현상이라 판단된다. 반면 M-2 모델의 경우, 온도에 따라 장치 전체에서 염 가스의 응축이 일어나기 때문에 M-1 모델 보다 절대적 염 가스의 양이 작게 나타나며 하부와 중심부의 염 가스 농도 차가 작게 나타난다. 위 결과를 통해 염의 응축 에 관련하여 M-1 모델 보다 M-2 모델이 CP의 거동 전산모사 에 더 적합하다고 판단된다. 시간에 따른 염 가스의 거동을 정량적으로 계산한 결과를 Fig. 8에 표현하였다. 증류된 염 가스의 양과 응축된 염 가스의 양은 염 가스의 변화량을 통 해 계산되었으며 잔여 염 가스의 양은 계산된 도메인 내에서
의 염 가스의 총 양을 나타낸다. Fig. 8 (a)의 M-1 모델과 비 교하여 Fig. 8 (b)의 M-2모델은 평형상태에서 염 가스의 양 이 2 배 작은 것으로 계산되는데 이는 응축 모델과 관련 있다. 평형상태의 잔여 염가스 양이 차이 나는 이유로, M-1의 경우 염 가스의 응축이 응축부에서만 일어나지만 $\mathrm{M}-2$ 의 경우 장 치 전체에서 응축이 일어난다. 따라서 초당 염 응축량이 M-1 모델보다 M-2 모델이 더 크기 때문에 도메인 내의 염 가스의 총량은 M-1 모델 보다 M-2 모델에서 더 작게 계산된다. 또한 두 모델 모두 응축부의 온도가 가장 낮기 때문에 염 가스의 응축이 가장 활발히 진행되는데, M-1 모델이 M-2 모델 보다 증류부부터 응축부까지의 농도구배가 작기 때문에 증류부부 터 응축부까지 염 가스가 이동하는데 걸리는 시간이 느려 증

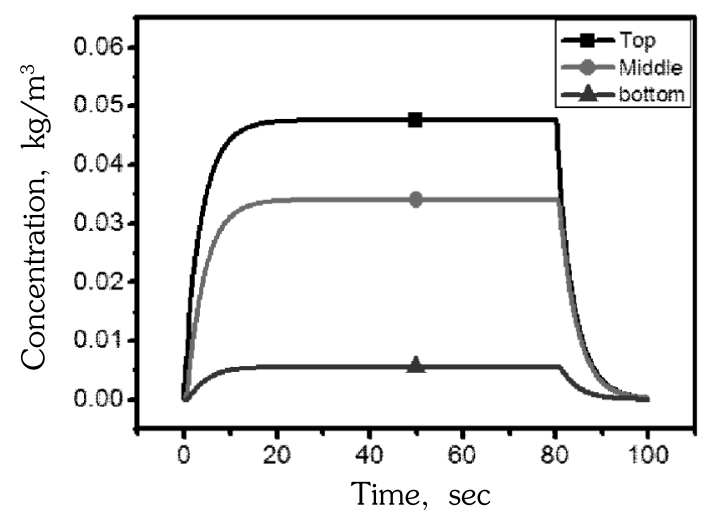

(a)

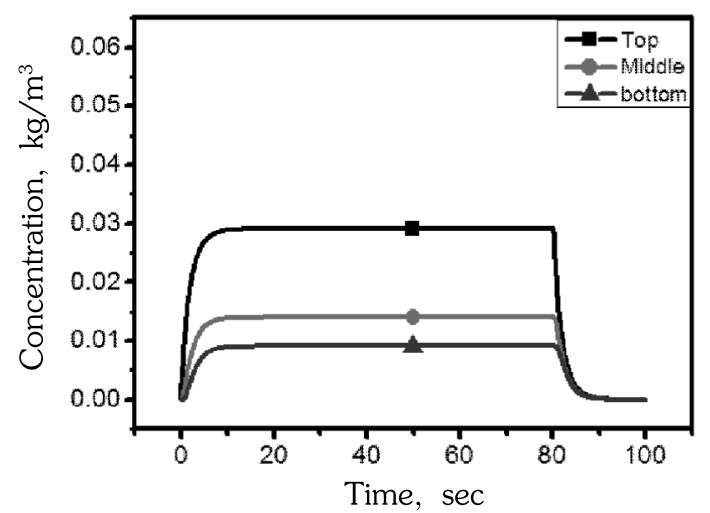

(b)

Fig. 7. Concentration comparison between M-1 and M-2 at three representative point. (top, middle and bottom) (a) M-1 (b) M-2

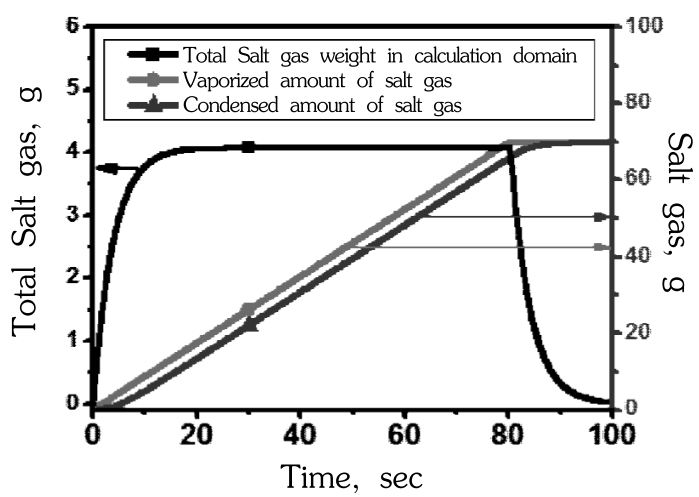

(a)

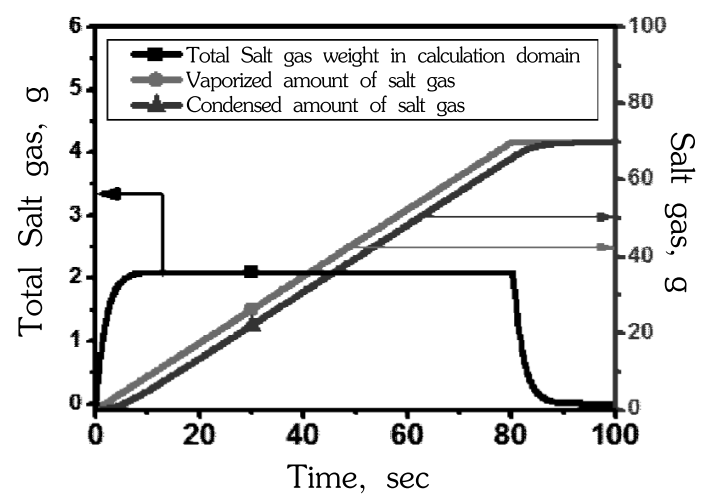

(b)

Fig. 8. Total amount of remained salt gas, vaporized salt gas and condensed salt gas in calculation domain. (a) M-1 (b) M-2 
류된 염가스가 응축되는데 걸리는 시간이 더 길어지게 된다. 이는 Fig. 7 의 염 가스의 증류가 완료 된 후, $\mathrm{CP}$ 장치의 운전 이 완료되는 구간에서 잔류 염 가스의 양 감소가 M-2 모델이 더 급격히 일어나는 것으로도 예측 할 수 있다.

$\mathrm{CP}$ 장치의 최적화된 방열판 크기를 도출하기 위해 방열 판의 직경에 따른 염 가스의 거동을 각 모델별로 $26-38 \mathrm{~cm}$ 의 범위에서 $4 \mathrm{~cm}$ 간격으로 전산모사 하였다. 방열판의 크기가 증가함에 따라 장치내 온도변화는 Fig. 9과 같다. 일반적으 로 $\mathrm{CP}$ 장치에서의 방열판은 증발부와 응축부를 최대한 단열 시킴으로써 온도구배를 크게 하여 응축속도를 증대시켜 공 정시간을 단축하기 위하여 설치하게 된다. 전산모사 결과 작 은 방열판 직경을 가지는 전산모사에서는 증류부와 방열판 이 만나는 지점에서 약간 온도 하강이 일어나게 된다. 하지 만 다른 부분에 있어 방열판의 직경 변화는 장치 내 온도변화 에 크게 영향이 없는 것으로 보인다. 이는 $\mathrm{CP}$ 장치내에서 $\mathrm{Ar}$ 가스의 압력이 극히 낮고 열 전달은 대부분 복사에 의해 이루 어지고 방열판과 $\mathrm{CP}$ 반응기 외벽 사이의 좁은 틈을 통한 복사 열의 전달은 그리 크지 않아 방열판 주위에서만 온도 차이가 나며, 전체적인 온도분포에는 큰 변화가 없는 것으로 판단된 다. Fig. 10은 두 모델의 시간에 따른 각 방열판 직경 별 장치 내 잔류 염 가스의 양을 나타낸 것이고, M-1 모델과 M-2 모 델 모두 방열판 직경이 증가하면 잔여 염 가스의 양은 증가하 는데 이는 온도 영향 보다 염의 이동 면적 축소에 따른 염의 이동속도 감소에 의해 장치 내에 잔류하고 있는 염 가스가 증 가한 것으로 판단된다. 특히 M-2 모델의 경우, 방열판의 직 경이 $38 \mathrm{~cm}$ 일 때, 잔여 염 가스의 양이 크게 증가하는 것으 로 보아 $\mathrm{CP}$ 장치 외벽과 방열판 사이의 거리가 $2 \mathrm{~cm}$ 이상 되

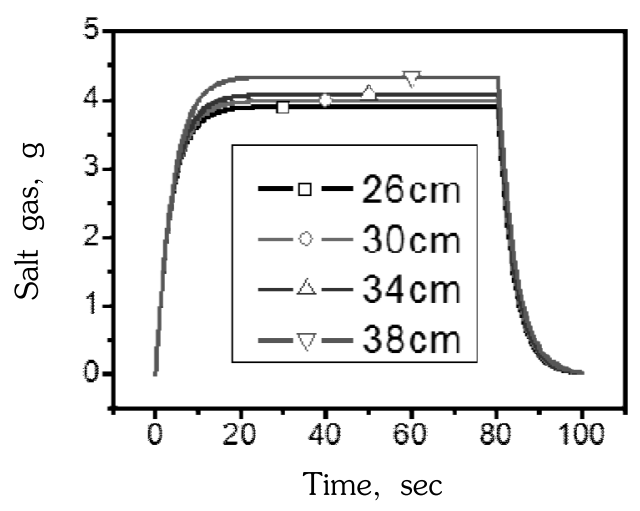

(a)
어야 염 가스의 원활한 이동이 이뤄진다고 판단된다. 이를 보 다 정량적으로 비교평가하기 위하여 M-1과 M-2모델에 대하 여 방열판 직경에 따른 잔류 염 양을 계산하여 Fig. 11에 나타 내었다. 이를 통해 방열판 직경이 증가함에 따라 잔류 염 양 이 두 모델 모두 증가하는 것을 알 수 있으며, 이는 방열판의 직경이 커질 경우 증류장치 외벽과 방열판 사이의 공간이 작 아 염 가스의 확산 경로가 줄어들어 나타나는 현상으로 해석 된다. 따라서 효과적인 염 가스의 이동을 위해서는 방열판과 장치 외벽 사이의 적절한 공간 확보가 중요하다고 판단된다.

한편, 증류장치 상부의 증발부와 응축부의 온도구배는 증류 속도를 증대시키는 중요한 요소로 판단되어 방열판의 두께 변화에 따른 해석을 실시하였다. 본 해석은 M-2 모델로

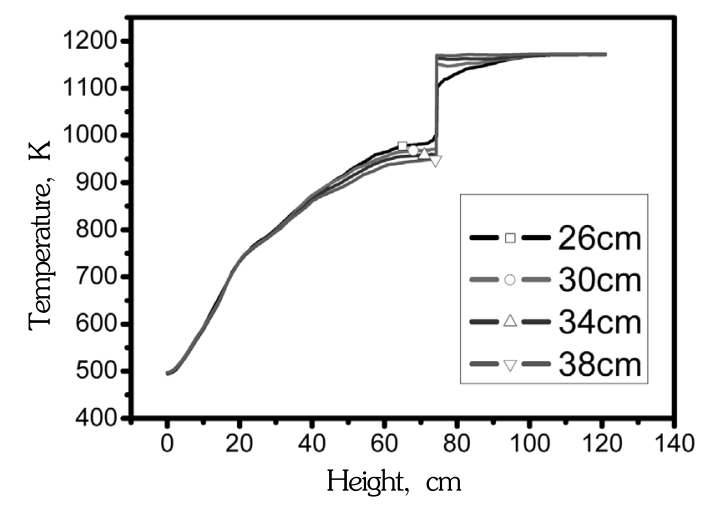

Fig. 9. Vertical temperature profiles according to size of thermal radiation shield.

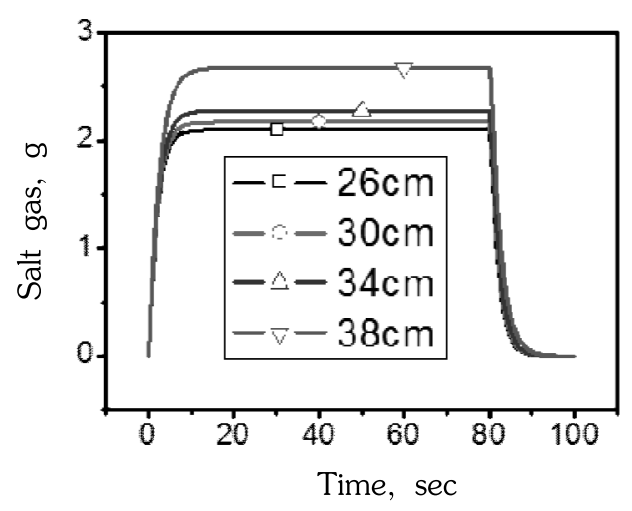

(b)

Fig. 10. Total amount of remained salt gas according to difference diameter of thermal radiation shield.(a) M-1 (b) M-2 
Bung Uk Yoo et al. : Performance Evaluation to Develop an Engineering Scale Cathode Processor by Multiphase Numerical analysis

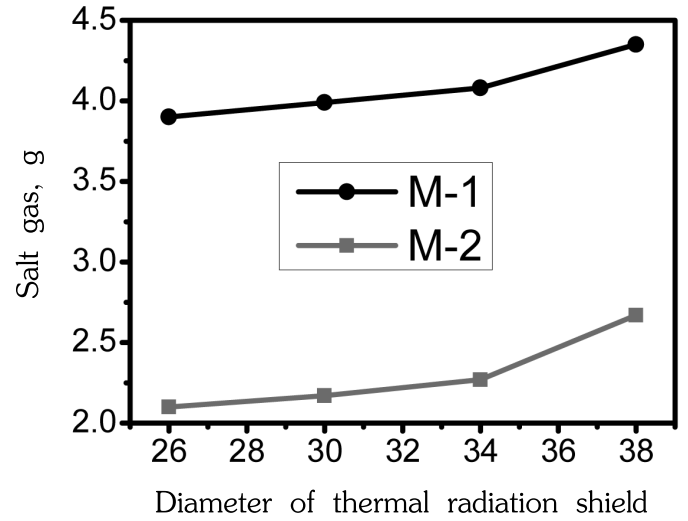

Fig. 11. Amount of remained salt gas at equilibrium stats according to the difference thermal radiation shield.

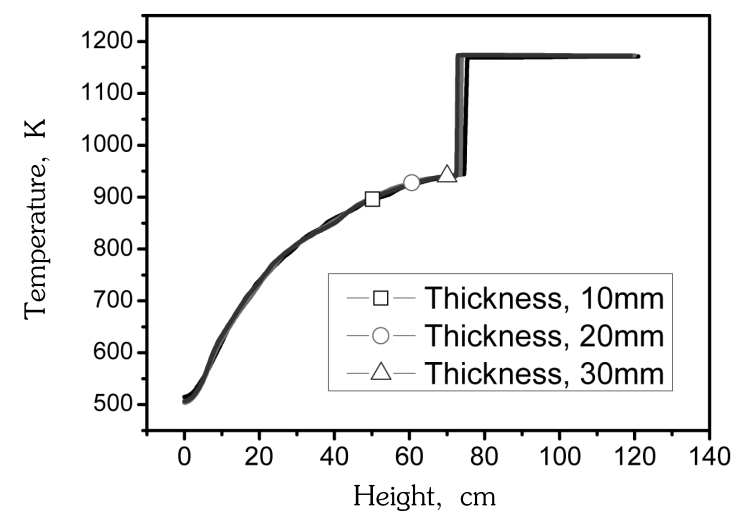

Fig. 12. Vertical temperature profiles according to thickness of thermal radiation shield.

진행 되었으며 이 때 온도 변화는 Fig. 12에 나타내었다. 전산 모사 결과 방열판 두께에 따른 온도변화는 거의 없다. 그 이 유는 방열판의 경계조건을, 단열체로 가정하였기 때문에 방 열판의 두께방향으로의 열 전달 차이는 없고, 열 전달은 방열 판과 반응기 벽면 사이의 틈을 통한 복사 열 전달이 지배적 이어서 그 차이가 크지 않은 것으로 판단된다. 그러나 실제 장치의 경우 방열판 소재간의 열 전달이 존재하므로 계산결 과와는 다소 상이한 결과가 나올 것을 예측할 수 있다. 한편 Fig. 13는 방열판 두께에 따른 장치 내의 잔류 염 양의 변화 를 시간에 따라 도시한 자료이다. 그림에서 확인할 수 있듯 이 공정 중 잔여하고 있는 염 가스의 양 변화도 두께 변화에 따라 큰 없으나 평형 상태일 때 최대 $0.1 \mathrm{~g}$ 의 차이를 보인다.

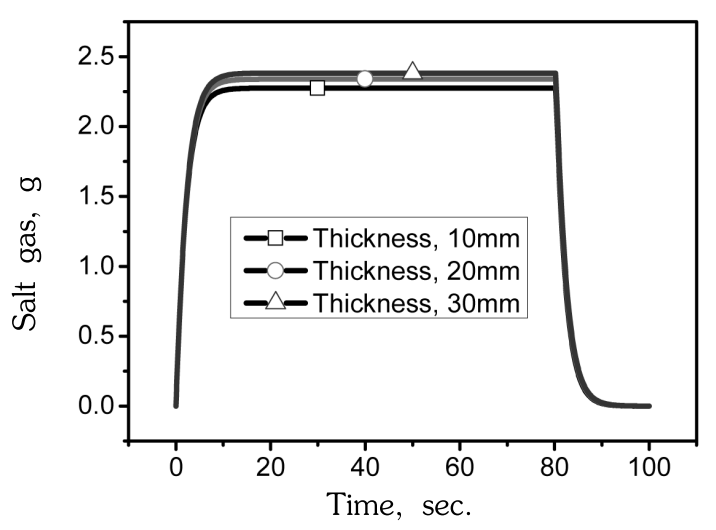

Fig. 13. Total amount of remained salt gas according to difference thickness of thermal radiation shield about M-2.

이는 방열판 두께가 증가함에 따라 방열판과 반응기 외벽 사 이를 통과하는 시간이 길어지기 때문이다. 그러나 초기 염의 장입량이 같을 때, $\mathrm{CP}$ 장치의 총 운전시간에는 차이가 거의 없기 때문에 방열판 직경과 두께 변화에 따른 운전 효율은 무 시할 수 있을 정도라고 판단된다. 따라서 $\mathrm{CP}$ 장치의 운전 효 율을 높이기 위해서는 방열판 직경의 변화로 인한 염 가스의 이동 속도 증가 보다, 염의 증류량을 늘리는 것이 효율적이라 판단된다. M-1, M-2 모델 모두 염의 증류와 염 가스의 이동 에 있어 Hertz-Langmuir 식과 Chapman-Enskog 이론을 기 반으로 하지만 염 가스의 응축 모델이 다르다. 염 가스의 응 축 방법이 다르게 되면 염 가스의 이동 해석 또한 변한다. 따 라서 두 모델의 전산모사 해석 결과에서 나타난 차이의 이유 는 염 가스의 응축 모델 변화에 따른 염의 이동 해석 결과 또 한 달라지게 되기 때문이다. 하지만 두 모델 모두 온도에 따 른 염의 증류와 염 가스의 거동, 응축을 계산하였지만 이는 온도와 압력에 따른 염과 염 가스의 밀도, 엔탈피, 엔트로피, 증기압 등이 동시에 고려되지 않고 전산모사 된 결과이다. 따 라서 이러한 염의 물성 값을 고려하게 되면 염 가스의 이동 과 응축 거동을 좀 더 물리적으로 실제 상황에 적합한 해석 을 할 수 있을 것이다. 본 모델은 장치의 기하학적 형상에 따 른 증류거동의 상대적 변화를 관찰하는 방안으로 유용하게 사용될 수 있으나 정량적 물리 량의 예측에는 아직 보완할 부 분이 상당부분 존재한다. 이러한 이유들 때문에 본 전산모사 연구는 모델의 적합성과 타당성을 판정하기 위해 추후 실험 적 검증이 이뤄지고 사용 염의 엔탈피 엔트로피, 열용량 등 이 고려된 상전이 모델 적용 등의 해석적 접근이 추가적으로 이루어질 예정이다. 


\section{4. 결론}

실험실규모의 $\mathrm{CP}$ 장치 전산모사를 통해 염 증류 거동을 확인 할 수 있었으며, M-2 모델이 실제 상황에 더 적합한 모 델임을 확인 할 수 있었다. M-1 모델이 CP 장치로써 실제 구 현 가능 할 때, 응축부에서만 염이 응축되므로 염 회수 측면 에서 이상적이나, 물리적으로 염의 증기압이 고려된 M-2 모 델이 더 타당하다고 판단된다. 따라서 차후 염 증류장치의 개 선이나, 규모확장 등에 있어 M-2 모델이 더욱 적합하며. 잔 여 염 가스의 양이 평형이 되는 점을 조절 함으로써 $\mathrm{CP}$ 장치 의 운전 시간을 최적화 할 수 있는 가능성을 확인하였다. 전 산모사 결과 $\mathrm{CP}$ 장치의 방열판의 직경 변화는 작은 온도변화 를 나타내지만 이는 장치의 운전시간에는 크게 영향을 미치 지 않는 것으로 계산되었다. 따라서 방열판, 반응기의 형상 변화 등 장치의 구조 변화 보다는 도가니의 직경변화를 이용 한 증류면적을 확장과 온도와 압력을 조건을 달리하여 증류 량을 증가시키는 방안이 더 효율 적이라고 판단된다.

\section{REFERENCES}

[1] V.A. Volkovich, "Treatment of Molten salt Wastes by Phosphate Precipitation: Removal of Fission Product Elements after Pyrochemical Reprocessing of Spent Nuclear Fuels in Chloride Melts", J. Nucl. Mat., 323, pp.49-56 (2003).

[2] Y.I. Chang, "The Integral Fast Reactor", Nucl. Technol., 88 (11), pp.129-138 (1989).

[3] H. Lee, G. Park, K. Kang, J. Hur, J. Kim, D. Ane, Y. Cho, and E. Kim, "Pyroprocessing Technology Development at KAERI", Nucl.Technol., 43(4), pp.317-328 (2011).

[4] K. Song, H. Lee, J. Hur, J. Kim, D. Ane, and Y. Cho, "Status of Pyroprocessing Technology Development in KOREA" Nucl. Technol.,42(2), pp.131-144 (2010). [5] A R. Brunsvold, P D. Roach, and B R. Westphal, "Design and Development of a Cathode Processor for Electrometallurgical Treatment of Spent Nuclear Fuel", Pro. of ICONE 8: 8thInternation Conferenceon Nuclear Engineering, April 2-6, USA, Baltimore (2000).
[6] B.R. Westphal, D. Vaden, T.Q. Hua, J.L. Willit, and D.V. Lang, "Recent Developments at the Cathode Processor for Spent Fuel Treatment", American Nuclear Society Fifth Topical Meeting DOE Spent Nuclear/Fuels and Fissile Materials Management, Sep. 17-20, USA, Charleston, South Carolina (2002).

[7] T.Kato, M. lizuka, T. Inoue, T. Iwai, andY.Arai, "Distillation of Cadmium from Uranium-Plutonium-Cadmium Alloy", J. Nucl. Mat., 340, pp.259-265 (2005).

[8] S. Park, D. Cho, G. Oh, J. Lee, S. Hwang, Y. Kang, H. Lee, E. Kim, and S. Park, "Salt Evaporation Behaviors of Uranium Deposits from an Electrorefiner", J. Radioanal. Nucl. Chem., 283, pp.171-176 (2010).

[9] K. Park, S. Kwon, S. Park, and J. Kim, "The Evaporation Characteristics of $\mathrm{LiCl}-\mathrm{KCl}$ Eutectic Salt from Uranium Deposit Using Batch Type Vacuum Distiller with Temperature Slope of Each Zones", J. Radional. Nucl. Cehm., 293, pp. 857-862 (2012).

[10] G.H.GeigerandD.R.Poirier, TransportPhenomenain Metallurgy, 1st ed., Addison-Wesley, Boston (1973).

[11] G. Bourgès, S. Faure, B. Fiers, S. Saintignon, O. Lemoine, D. Cardona-Barrau, and D. Devillard, "Vacuum Distillation of Plutonium Pyrochemical Salts", Procedia Chemistry, 7, pp.731-739 (2012).

[12] K. Chatterjee, D. Dollimore, and K S. Alexander, "Calculation of Vapor Pressure Curves for Hydroxy Benzoic Acid Derivatives Using Thermogravimetry", Thermochimica Acta, 392-393, pp.107-117 (2002).

[13] L, L. Wang, T. C. Wallace, SR., F. G. Hampel, and J. H. Steele, "Vacuum Evaporation of $\mathrm{KCl}-\mathrm{NaCl}$ Salts: Part II. Vaporization-Rate Model and Experimental Results", Metall. Mater. Trans. B, 27B, pp.434-443 (1996).

[14] ANSYS, Inc. CFX-Solver Theory Guide, Release 12.0, (2009).

[15] B. E. Poling J. M. Prausnitz, and J. P. O'Connel., The Properties of Gas and Liquids. 1st ed., McGRAW-HILL, New York (2001).

[16] T. Koyama, K. Uozumi, M. Iizuka, Y. Sakamura, and K. Kinoshita, "Pyrometallurgy Data Book", CRIEPI report, T93033, pp.41 (1995). 